УДК 657.421 .3

DOI: https://doi.org/10.26642/jen-2020-4(94)-74-78

Закарпатський угорський інститут імені Ференцуа Ракоці II

В.В. Поплавська, аспірант

Державний університет «Житомирська політехніка»

\title{
Облікове відображення господарських операцій з придбання бренд-активів підприсмства
}

Визначено, щзо одним із основних показників ставлення споживача до бренда є лояльність. Розглянуто показники, за якими можна визначити міру лояльності споживачів до бренду. Визначено загальні характеристики бренда, зокрема: бренд існує в свідомості споживача, він має унікальний набір цінностей, призначений для ідентифікації товарів або послуг виробника; бренд - це об'єкт інтелектуальної власності, щчо складається із сукупності матеріальних, нематеріальних елементів і відображає характеристики товару, його унікальні ознаки; бренд маркетинговий інструмент, щуо має певну цінність для продавців та споживачів товарів, сприяє економічному розвитку підприємства і формуванню взаємовигідних відносин з партнерами; на відміну від торгової марки бренд не можна реєструвати і контролювати, а також прив'язати до якогось географічного місия. Встановлено існуючі підходи до побудови методики бухгалтерського обліку торгових марок та брендів, які можуть відрізнятися залежно від того, чи придбані такі активи або були створені самим підприсмством. Уточнено питання нарахування амортизації на придбані права на торгову марку. Розкрито порядок передачі виключних прав власності на торгову марку. Запропоновано господарські операції придбання виключно майнових прав на торгову марку.

Ключові слова: бренд; брендинг; торгова марка; нематеріальний актив; облік торговельних марок.

Постановка проблеми: У сучасному висококонкурентному середовищі, що переповнене величезною кількістю схожих товарів, робіт та послуг, споживач все частіше здійснює вибір на основі суб'єктивних факторів, а не об'єктивних, внаслідок чого бренд компанії-виробника стає все більш важливим критерієм вибору. Ця характеристика формується в суспільстві протягом досить тривалого часу і гарантує належний рівень якості та соціальної ідентичності. Тисячі компаній у всіх частинах світу вкладають сотні мільйонів доларів для побудови свого бренда, своєї позитивної репутації, найважливішого нематеріального активу, який не $\epsilon$ відчутним i який важко виміряти, який накопичується і будується роками. Ця думка про бренд у різних варіаціях звучить сьогодні на конференціях, 3'являється на сторінках ділової преси, використовується в розробці корпоративних бізнес-планів.

До нематеріальних активів можуть належати різні предмети і майнові права. Бренд також відноситься до нематеріальних активів, оскільки створює ринкові вигоди для підприємства, впливаючи на обсяги реалізації продукції, товарів, послуг тощо. В процесі розгляду ролі бренда як активу неминуче постає питання стосовно його вимірювання та порядку облікового відображення. Оскільки нематеріальні активи як окремий об'єкт в бухгалтерському обліку почали використовувати порівняно нещодавно, то щодо деяких питань відображення в обліку бренд-активів відсутнє однозначне рішення, що зумовлює необхідність привернення уваги до цієї проблематики.

Аналіз останніх досліджень та публікацій. Сутність та порядок створення брендів у своїх працях розглядали Ж.-Н. Капферер, Д.Аакер, Т.Нільсон, Е.Райс, Д.Траут, К.Келлер, Д.Огілві та ін. Дослідженню брендингу як окремого виду діяльності присвятили свої роботи такі дослідники в сфері маркетингу, як Ф.Котлер, Л. Де Чернатоні, Т.Левітт, О.О. Власенко, А.В. Возичок, О.В. Зозульов, В.Я. Кардаш, Л.А. Мороз, Ю.Нестерева, В.П. Пелішенко, Є.В. Ромат, С.О. Солнцев, А.О. Старостіна, О.К. Шафалюк, Л.М. Шульгіна та ін.

Викладення основного матеріалу. Останнім часом в економічному співтоваристві широко обговорюється питання про доцільність відображення вартості брендів в активній частині балансу. Розриви між балансовою і ринковою вартістю компаній $\epsilon$ настільки великими (і продовжують збільшуватися), що в бухгалтерському середовищі були змушені прийти до компромісу. 3 одного боку, на хвилі поглинань і продажів активів відомих компаній виникла думка про те, що відмова від включення ціни брендів в бухгалтерський баланс призводить до заниження вартості фірм. 3 іншого боку, в традиційному обліку інвестиції у створення бренда розглядаються як витрати, що протиставляються поточним прибуткам. Сьогодні багато науковців пишуть про бренд компанії і як теоретики, так і практики, пропонують багато його визначень. 
Так Д.Аакер зазначив, що бренд - це особлива назва або символ, призначений для ідентифікації товарів або послуг одного продавця або групи продавців, а також для диференціації цих товарів або послуг від схожих продуктів конкурентів [1]. Бренд - це нематеріальний актив, але надзвичайно важливий компонент діяльності компанії, те, що вона собою символізує [6]. В свою чергу О.В. Зозульов розглядав бренд як вдало диференційована торгова марка, тобто така, що у свідомості споживача асоціюється 3 певними перевагами чи вигодами, чітко вирізняється 3-поміж марок конкурентів та характеризується високим рівнем лояльності з боку споживачів [3]. Бренд - сукупність характеристик товару (його атрибутів, уявлень і знань споживачів про товар), елементів торгової марки (логотип, назва та звуковий ряд) і торгового знака (юридичний захист) [2].

Незважаючи на безліч визначень, у них можна простежити загальні характеристики цього об'єкта, зокрема: бренд існує в свідомості споживача, він має унікальний набір цінностей, призначений для ідентифікації товарів або послуг виробника; бренд - це об'єкт інтелектуальної власності, що складається iз сукупності матеріальних, нематеріальних елементів і відображає характеристики товару, його унікальні ознаки; бренд - маркетинговий інструмент, що має певну цінність для продавців та споживачів товарів, сприяє економічному розвитку підприємства і формуванню взаємовигідних відносин 3 партнерами; на відміну від торгової марки бренд не можна реєструвати і контролювати, а також прив’язати до якогось географічного місця.

Вимірювання активу, його оцінка вимагають визначення кінцевого числа позицій, які зможуть слугувати вимірювачами. Загальноприйнятого опису вимірників на сьогодні не існує, однак спроби його створити займають пріоритетні місця в сучасній теорії брендингу. У підході до цієї проблеми можна вирізнити два рівні: перший містить у собі спроби виміряти бренд-актив безпосередньо через ринкову позицію цього бренда (зазвичай через ставлення споживача), другий - через виокремлення універсальних категорій виміру (зазвичай через фінансові показники). Прикладом підходу «першого рівня» може слугувати методика Д.Аакера, який зауважив п’ять рівнів ставлення споживача до бренда, які дозволяють проаналізувати величину бренд-активу: 1 - у споживача відсутня лояльність до торгової марки; 2 - у споживача немає причин змінювати пристрасть до цього товару; 3 - за умови зміни бренда споживач зазнає збитків; 4 - споживач цінує цей бренд; 5 - споживач відданий бренду [1]. Найменш прихильною до бренда $\epsilon$ перша категорія споживачів. Найімовірніше, вони орієнтуються на ціну й для них бренд не має значення під час вибору товару. Наступна категорія споживачів не відрізняється високою лояльністю до марки - на цей сегмент дуже складно впливати, тому що він залежить від умов, які пропонує конкуруюче виробництво; за інших рівних умов споживачі цього сектору не мобільні. Наступна група споживачів вже важлива для бренда, так як у них є «витрати на переорієнтацію», і через це вони віддають перевагу цьому бренду. У четвертої групи споживачів зв'язок з брендом існує на емоційному, чуттєвому рівні, й вони грають істотну роль у формуванні бренд-активу. I, нарешті, остання група для бренд-активу є основним ресурсом: вони не лише самі постійно споживають цей товар, але також впливають на ринок і на оточуючих.

Таким чином, основним показником ставлення споживача до бренда є лояльність. Цей факт дозволяє зробити висновок, що величина бренд-активу безпосередньо залежить від тих споживачів, у яких бренд викликає позитивні емоції. І яким би не було сприйняття бренда споживачами, саме це сприйняття надає бренду властивості активу. Всі ті показники, за якими можна визначити міру лояльності споживачів до бренда, можна назвати вимірювачами бренд-активу [9]. Це - прихильність до бренда; популярність імені; відчутна якість; асоціації, пов'язані з брендом; інші його активи. Після того, як складено уявлення про споживчу лояльність, необхідно оцінити актив бренда з фінансових позицій [2].

Розглянувши основні аспекти концепції активу бренда, можна зробити кілька основних висновків:

1) безумовно, у підході до бренда як до справжнього активу компанії є вагомі підстави - переважно практичного характеру. Виникає необхідність приведення теоретичної бази у відповідність до реального стану справ, за якого загальна сума активів компаній перестає явно корелювати із сумою їх матеріальних активів. Динаміка розвитку більшості компаній за останні роки демонструє випереджаюче зростання нематеріальних активів, особливо брендів. Основними показниками того, що бренд є справжнім активом, можна вважати, наприклад, системи франчайзингу (в яких покупець франшизи, фактично, платить безпосередньо за бренд), а також таке явище, як преміум-ціна (тобто цінова надбавка за бренд обіцянку);

2) незважаючи на явну актуальність проблеми формалізації бренд-активу, робота в цьому напрямі розпочалася зовсім нещодавно, й у більшості випадків її результати ще не відповідають тим вимогам, які було б логічно пред’являти до вимірювання та обліку реальних активів;

3) безумовною є суперечливість тих позицій, 3 яких оцінюється бренд-актив, навіть коли він вимірюється. 3 одного боку, ця суперечливість свідчить про нетривалість історії вивчення питання, 3 іншого - про різноманітність якостей самого об'єкта. Будучи сполучною ланкою між споживачем i виробником, бренд об'єднує в собі погляди першого і фінансові цілі другого, що створює труднощі під час спроби визначити його інтегральні характеристики як активу. 
Щодо існуючих підходів до побудови методики бухгалтерського обліку бренд-активів, то вони можуть відрізнятись залежно від того, чи придбані такі активи або були створені самим підприємством. Для початку розглянемо перший варіант відображення в бухгалтерському обліку внутрішньо створених бренд-активів. Якщо підприємство вирішило самостійно створювати такий актив, тоді згідно з П(с)БО 8 всі витрати, спрямовані на бренд-актив, будуть відображатися у складі витрат звітного періоду. Включаємо всі витрати на збут та відображаємо на рахунку 93 [6].

Також це твердження відповідає п. 64 МСБО 38 «Нематеріальні активи», де вказано, що видатки на внутрішньо генеровані бренди, заголовки, назви видань, переліки клієнтів та інші подібні своєю сутністю об'єкти не можна відокремити від витрат на розвиток бізнесу в цілому. Отже, такі об'єкти не визнаються як нематеріальні активи [4]. Відповідно всі витрати, понесені підприємством на просування створеної ним торгової марки (реклама, пресінформація, телемаркетинг, маркетинг взаємовідносин та інше), мають списуватися на витрати відповідно до п. 9 П(с)БО 8 «Нематеріальні активи» та листа Міністерства фінансів України від 11.09.2006 р. № 31-34000-10-10/18842 [6].

Щодо операцій 3 надходження бренд-активів в бухгалтерському обліку як об'єктів нематеріальних активів, то вони можуть бути відображені як: операції купівлі, безоплатного отримання, внесення до статутного капіталу. Також необхідно розуміти, що підприємство, як тільки вирішило створити бренд, спочатку купує або створює торгову марку. 3 часом за допомогою реклами, пресінформації, маркетингу торгова марка розкручується та поступово стає брендом (бренд-активом) підприємства. Якщо мова йде про придбання прав на торгову марку на підставі договору про передачу виключно майнових прав інтелектуальної власності, то для початку укладається такий договір відповідно до ст. 1113 ЦКУ [8].

За договором про передання виключних майнових прав інтелектуальної власності одна сторона (особа, що має виключні майнові права) передає другій стороні частково або у повному складі ці права відповідно до закону та на визначених договором умовах [8]. На цьому етапі потрібно звернути увагу, щоб у договорі було чітко прописано, чи передаються виключно майнові права чи лише частина прав на торгову марку. Відповідно до ч. 2 ст. 1114 ЦКУ факт передачі виключно майнових прав інтелектуальної власності підлягає державній реєстрації. Після цього орган, який уповноважений реєструвати торгові марки, має внести зміни до реєстру про нового власника торгової марки. Ці зміни зазначаються у додатку до Свідоцтва, набувач права на торгову марку стає власником виключно майнових прав на торгову марку. Якщо ж передається лише якась певна частина прав на торгову марку, тоді після сплати державного мита за видачу Свідоцтва Державна служба інтелектуальної власності України має видати нове Свідоцтво на ім'я особи, яка отримає частку права [8]. Після придбання вже зареєстрованої торгової марки в бухгалтерському обліку створюється новий об'єкт нематеріального активу. Вартість торгової марки складатиметься 3:

- вартості придбання;

- суми державного мита під час отримання додатка до Свідоцтва;

- суми непрямих податків, які не підлягають відшкодуванню;

придатний до експлуатації (п. 10, 11 П(с)БО 8) [6].

Всі зазначені вище витрати до отримання свідоцтва в бухгалтерському обліку відображаються на субрахунку 154 «Придбання (створення) нематеріальних активів», а після отримання свідоцтва i введення в експлуатацію - списуються по дебету субрахунку 123 «Право на комерційні позначення» (табл. 1). Щодо амортизації, то відповідно до п. 29 П(с)БО 8 нарахування амортизації починається 3 місяця, наступного за місяцем, у якому нематеріальний актив було введено в експлуатацію. Взагалі до нарахування амортизації права на торгову марку переважно виникає багато питань [6].

Таблиия 1

Господарські операчії придбання виключно майнових прав на торгову марку

\begin{tabular}{|c|l|c|c|}
\hline № & \multicolumn{1}{|c|}{ 3міст операції } & Дm & $\mathrm{Km}$ \\
\hline 1 & $\begin{array}{l}\text { Відображено плату за отримання виключно майнових прав на торгову марку } \\
\text { на 10 років }\end{array}$ & 371 & 311 \\
\hline 2 & Відображено податковий кредит & 641 & 644 \\
\hline 3 & $\begin{array}{l}\text { Відображено витрати, пов’язані з реєстрацією факту передачі прав на торгову } \\
\text { марку }\end{array}$ & 154 & 631 \\
\hline 4 & Відображено отримані права на торгову марку (отримано свідоцтво) & 154 & 631 \\
\hline 5 & Відображено списання податкового кредиту & 644 & 631 \\
\hline 6 & Відображено залік заборгованостей & 371 & 631 \\
\hline 7 & $\begin{array}{l}\text { Відображено придбання виключних прав на торгову марку та введено в } \\
\text { експлуатацію нематеріальний актив підприємства }\end{array}$ & 123 & 154 \\
\hline 8 & Відображено нарахування амортизації нематеріального активу & 93 & 133 \\
\hline
\end{tabular}


Під час розрахунку суми амортизації основним показником є строк корисного використання торгової марки, котрий відповідно до пП. 25-31 П(с)БО 8 підприємство самостійно обирає. Також під час визначення строку корисного використання потрібно враховувати відповідно до п. 26 П(с)БО 8:

- строки корисного використання подібних активів;

- моральний знос, що передбачається;

- правові або інші подібні обмеження щодо строків його використання;

- очікуваний спосіб використання нематеріального активу підприємством;

- залежність строку корисного використання нематеріального активу від строку корисного використання інших активів підприємства [6].

Також багато питань виникає 3 нарахуванням амортизації на права, вартість яких 3 часом не зменшується та які будуть приносити прибуток протягом всього періоду діяльності підприємства і не мають визначеного строку корисного використання. Так як у П(с)БО 8 вказано, що нематеріальні активи 3 невизначеним строком корисного використання амортизації не підлягають. До нематеріальних активів 3 невизначеним строком корисного використання належать ті, щодо яких підприємством не визначено обмеження строку, протягом якого очікується збільшення грошових коштів (чи їх еквівалентів) від використання таких нематеріальних активів [6]. На думку авторів, якщо підприємство придбало право на торгову марку та отримало Свідоцтво про реєстрацію торгової марки, то 3 цього ж моменту може нараховувати амортизацію на такий вид нематеріального активу. Щодо строку корисного використання доречно зазначати 10 років, так як Свідоцтво на реєстрацію торгової марки видається на 10 років.

Щодо документального оформлення приймальна комісія, призначена наказом керівника, складає Акт введення в господарський оборот об'єкта права інтелектуальної власності у складі нематеріальних активів (НА-1) відповідно до наказу Мінфіну від 22.11.2004 р. № 732 [5]. Після підписання комісією Акта та затвердження керівником, його передають у бухгалтерію. Після цього в бухгалтерії створюється Інвентарна картка обліку об'єкта права власності у складі нематеріальних активів. (НА-2). Також пропонуємо для покращення роботи розробити форму «Звіту аналітичного обліку витрат на розробку торгової марки». Звіт необхідний для внесення сум витрат, котрі підприємство понесло на створення торгової марки до моменту складання Акта введення в господарський оборот об'єкта права інтелектуальної власності у складі нематеріальних активів.

Висновки. Одним з основних показників ставлення споживача до бренда є лояльність. Цей показник дозволяє визначити, що величина бренд-активу безпосередньо залежить від тих споживачів, у яких бренд викликає позитивні емоції. I яким би не було сприйняття бренда споживачами, саме це сприйняття надає бренду властивості активу. Всі ті показники, за якими можна визначити міру лояльності споживачів до бренда, можна назвати вимірювачами бренд-активу.

Незважаючи на явну актуальність проблеми формалізації бренд-активу як об'єкта обліку, робота в цьому напрямі розпочалася зовсім нещодавно, й у більшості випадків ії результати ще не відповідають тим вимогам, які $є$ достатньо необхідними для забезпечення достовірного вимірювання та обліку реальних активів. Будучи сполучною ланкою між споживачем і виробником бренд об'єднує в собі погляди першого й фінансові цілі другого, що створює труднощі під час спроби визначити його інтегральні характеристики як активу, який може відображатися в системі обліку.

Щодо існуючих підходів до побудови методики бухгалтерського обліку торгових марок та брендів, то вони можуть відрізнятися залежно від того, чи придбані такі активи або були створені самим підприємством. Щодо операцій з надходження торгової марки в бухгалтерському обліку як об'єктів нематеріальних активів, то вони можуть бути відображені як операції купівлі, безоплатного отримання, внесення до статутного капіталу. Якщо мова йде про придбання прав на торгову марку на підставі договору про передачу виключно майнових прав інтелектуальної власності, для початку укладається такий договір відповідно до Цивільного кодексу України.

Зважаючи на неопрацьованість і суперечливість властивостей бренд-активу, проблемні аспекти його облікового відображення та оцінки ні в якому разі не можна вважати повністю вирішеними. Будучи гнучким і рухомим інструментом бізнесу бренд-актив заслуговує самого уважного ставлення на кожному етапі розробки стратегії компанії, і для ефективного управління яким необхідним є формування дієвої системи інформаційного забезпечення.

\section{Список використаної літератури:}

1. Аакер А.Д. Создание сильных брендов / А.Д. Аакер ; пер. с англ. - М. : Издательский дом Гребенникова, 2003. - 440 с. [Электронный ресурс]. - Режим доступа : https://www.studmed.ru/view/aaker-da-sozdaniesilnyh-brendov_0cb686455ff.html?page=43.

2. Велещук С.С. Бренд-менеджмент в стратегічному розвитку підприємств / C.C. Велещук [Електронний pecypc]. - Режим доступу : http://www.disslib.org/brend-menedzhment-v-stratehichnomu-rozvytkupidpryyemstv.html.

3. Девис С.М. Управление активами торговой марки / С.М. Девис. - СПб. : Питер, 2001. - 272 с. 
4. Зозульов О.В. Брендинг чи антибрендинг. Що вибрати в Україні? / О.В. Зозульов // Маркетинг в Україні. 2002. - № 4. - C. 26-28.

5. МСБО 38 «Нематеріальні активи» [Електронний ресурс]. - Режим доступу : https://zakon.rada.gov.ua/laws/show/929_050.

6. Про затвердження типових форм первинного обліку об'єктів права інтелектуальної власності у складі нематеріальних активів : Наказ Міністерства фінансів України [Електронний ресурс]. - Режим доступу : https://zakon.rada.gov.ua/laws/show/z1580-04\#Text.

7. П(с)БО 8 «Нематеріальні активи» [Електронний ресурс]. - Режим доступу : https://zakon.rada.gov.ua/laws/show/z0750-99.

8. Третяк В.П. Актив бренду: вимірювачі, оцінки (Ч. 3) / В.П. Третяк // Галузеві ринки. - 2008. - № 5-6 (18) [Електронний ресурс]. - Режим доступу : https://refdb.ru/look/1992872-p2.html.

9. Цивільний кодекс України [Електронний ресурс]. - Режим доступу : https://zakon.rada.gov.ua/laws/show/43515\#Text.

10. Шилина Ю. Безупречность - как основа капитала / Ю.Шилина // propel.ru: рекламный портал. - 2010 [Электронный ресурс]. - Режим доступа : http://propel.ru/pub/290.php.

\section{References:}

1. Aaker, A.D. (2003), Sozdanie sil'nykh brendov, transl. from Engl., Izdatel'skii dom Grebennikova, M., 440 p., [Online], available at: https://www.studmed.ru/view/aaker-da-sozdanie-silnyh-brendov_0cb686455ff.html?page=43

2. Veleshhuk, S.S., Brend-menedzhment $v$ strategichnomu rozvytku pidpryjemstv, [Online], available at: http://www.disslib.org/brend-menedzhment-v-stratehichnomu-rozvytku-pidpryyemstv.html

3. Devis, S.M. (2001), Upravlenie aktivami torgovoi marki, Piter, SPb., 272 p.

4. Zozul'ov, O.V. (2002), «Brendyng chy antybrendyng. Shho vybraty v Ukrai'ni?», Marketyng v Ukrai'ni, No. 4, pp. 26-28.

5. MSBO 38 «Nematerial'ni aktyvy», [Online], available at: https://zakon.rada.gov.ua/laws/show/929_050

6. Ministerstvo finansiv Ukrai'ny, Pro zatverdzhennja typovyh form pervynnogo obliku ob 'jektiv prava intelektual'noi' vlasnosti u skladi nematerial'nyh aktyviv, [Online], available at: https://zakon.rada.gov.ua/laws/show/z158004\#Text

7. Ministerstvo finansiv Ukrai'ny, $P(s) B O \quad 8$ «Nematerial'ni aktyvy», [Online], available at: https://zakon.rada.gov.ua/laws/show/z0750-99

8. Tretjak, V.P. (2008), «Aktyv brendu: vymirjuvachi, ocinky (Part 3)», Galuzevi rynky, No. 5-6 (18), [Online], available at:https://refdb.ru/look/1992872-p2.html

9. Cyvil'nyj kodeks Ukrai'ny, [Online], available at: https://zakon.rada.gov.ua/laws/show/435-15\#Text

10. Shilina, Yu. (2010), «Bezuprechnost' - kak osnova kapitala», propel.ru: reklamnyi portal, [Online], available at: http://propel.ru/pub/290.php

Стойка Наталія Степанівна - кандидат економічних наук, доцент кафедри бухгалтерського обліку і аудиту Закарпатського угорського інституту імені Ференца Ракоці II.

Наукові інтереси:

- проблеми теорії та практики бухгалтерського управлінського обліку;

- обліково-інформаційне забезпечення системи управління.

E-mail: stojkanataliya@gmail.com.

Поплавська Вікторія Вікторівна - аспірант кафедри обліку і аудиту Державного університету «Житомирська політехніка».

Наукові інтереси:

- бухгалтерський облік операцій з бренд-менеджменту;

- бренд-менеджмент;

- бренд-активи.

https://orcid.org/0000-0002-0531-9796.

E-mail: poplavskaya.v.24@gmail.com. 